\title{
Polymerase chain reaction (PCR) amplification of RNA of striped jack nervous necrosis virus (SJNNV)
}

\author{
Toyohiko Nishizawa ${ }^{1}$, Koh-ichiro Mori ${ }^{1}$, Toshihiro Nakai ${ }^{1}$, Iwao Furusawa ${ }^{2}$, \\ Kiyokuni Muroga ${ }^{1}$
}

${ }^{1}$ Faculty of Applied Biological Science, Hiroshima University, Higashi-hiroshima 724, Japan

${ }^{2}$ Faculty of Agriculture, Kyoto University, Kyoto 606, Japan

\begin{abstract}
The polymerase chain reaction (PCR) was used to amplify a portion of the coat protein gene (RNA2) of striped jack nervous necrosis virus (SJNNV), the causative agent of viral nervous necrosis (VNN) of larval striped jack Pseudocaranx dentex. Based on the sequence data of SJNNV RNA2, 2 forward (F1 and F2) and 3 reverse (R1, R2 and R3) PCR primers were synthesized and the 5 potential target regions were amplified with a combination of these primers. After reverse transcription. of genomic RNA extracted from SJNNV and 25 cycles of PCR amplification, products of the expected size were detected separately on agarose gels stained with ethidium bromide. Southern blot hybridization confirmed that all of the amplified products were specific to CDNA of SJNNV RNA2. Two primer sets, F1-R2 and F2-R3, produced the specified 180 bp and 430 bp products. The PCR system, using the F2-R3 primer set, was able to detect $100 \mathrm{fg}$ of SJNNV RNA after 25 cycles and was also able to efficiently amplify the target region of SJNNV gene in the total nucleic acids extracted from larval striped jack affected with VNN.
\end{abstract}

KEY WORDS: Viral nervous necrosis $\cdot$ Nodavirus $\cdot$ PCR

\section{INTRODUCTION}

Striped jack nervous necrosis virus (SJNNV) is the causative agent of viral nervous necrosis (VNN) in hatchery-reared larvae of striped jack Pseudocaranx dentex (Mori et al. 1992, Arimoto et al. 1993). SJNNV has been identified as a member of the family Nodaviridae based on the properties of its structural proteins and nucleic acids (Mori et al. 1992). The spherical unenveloped virus, about $25 \mathrm{~nm}$ in diameter, contains 2 single-stranded, positive-sense, non-polyadenylated RNAs of $1.01 \times 10^{6} \mathrm{Da}$ (RNA1) and $0.49 \times 10^{6}$ Da (RNA2). RNA1 encodes a non-structural protein of $100 \mathrm{kDa}$ and RNA2 encodes a structural protein of $42 \mathrm{kDa}$ of the virus. The gene of RNA2 consisting of $1.48 \mathrm{~kb}$ has been cloned and sequenced, and the open reading frame determined (Mori et al. unpubl.).

In VNN disease of larval striped jack, the central nervous system is affected and numerous virus particles exist in the cytoplasm of infected nerve cells. Because virus isolation using fish cell lines has not been success- ful, cell culture techniques cannot be applied at present for the detection of the virus. Arimoto et al. (1992) developed an enzyme-linked immunosorbent assay (ELISA) using a rabbit anti-SJNNV serum for the detection of viral antigens from diseased larvae and gonads of parental spawners. However, the sensitivity of this ELISA was not high enough to detect the virus from fish in the latent or carrier state.

Reverse transcription followed by polymerase chain reaction ( $P C R$ ) is a powerful technique for amplification of RNA (Innis et al. 1990, Xu \& Larzul 1991), which has been applied for the detection of infectious hematopoietic necrosis virus (Arakawa et al. 1990). This paper describes a PCR amplification technique as a rapid and sensitive method for the detection of SJNNV.

\section{MATERIALS AND METHODS}

Preparation of viral nucleic acid. The SJNNV was purified from hatchery-reared larval striped jack af- 
fected with VNN following the procedure described by Mori et al. (1992). Briefly, a pooled sample of diseased larvae (net weight: $50 \mathrm{~g}$ ) from an outbreak at Nagasaki Prefecture, Japan, in 1992 was homogenized with chloroform - $100 \mathrm{mM}$ Tris-HCl buffer (pH 7.2) containing $1 \mathrm{mM}$ EDTA and $2 \mathrm{mM} 2$-mercaptoethanol. After centrifugation at $8000 \times g$ for $20 \mathrm{~min}$, the supernatant was centrifuged at $100000 \times g$ for $2.5 \mathrm{~h}$. The resultant pellet was resuspended in $100 \mathrm{mM}$ Tris- $\mathrm{HCl}$ containing $1 \mathrm{mM}$ EDTA and the virus was purified by 10 to $40 \%$ sucrose gradient centrifugation $(80000 \times \mathrm{g}, 2 \mathrm{~h})$ and $36 \% \mathrm{CsCl}$ equilibrium density gradient centrifugation $(210000 \times g, 16$ h). Nucleic acids of SJNNV were extracted with phenol saturated with TE buffer (10 mM Tris- $\mathrm{HCl}, \mathrm{pH} 8.0,1 \mathrm{mM}$ EDTA) followed by a mixture of chloroform and isoamyl alcohol (24:1) The nucleic acids were precipitated by addition of 0.1 volume of $3 \mathrm{M}$ ammonium acetate and 2.5 volumes of $100 \%$ ethanol, dried, and resuspended in diethyl pyrocarbonate treated water.

Diseased larvae of striped jack from the same lot as described above and normal larvae were homogenized with TE buffer containing SDS (1\%) and proteinase $\mathrm{K}$ $\left(1 \mathrm{mg} \mathrm{ml} \mathrm{m}^{-1}\right)$. After incubation at $37^{\circ} \mathrm{C}$ for $30 \mathrm{~min}$, the total nucleic acids were extracted and precipitated by the procedure described above.

Primer design for PCR amplification. Five DNA oligonucleotide primers for PCR amplification of SJNNV gene were designed based on sequence data of the SJNNV RNA2 (Mori et al. unpubl.). These in- cluded 2 forward (sense) primers (F1 and F2) and 3 reverse (antisense) primers (R1, R2 and R3). Primer locations and sequences are shown in Fig. 1 and Table 1. Each primer consisted of 20 nucleotides and had a Tm between 63.6 and $65.4^{\circ} \mathrm{C}$. These primers were synthesized using a Gene Assembler Special (Pharmacia) and established protocols. Target regions expected to be amplified by these primers were 1147 bp (T1) from F1 to $R 1,875 \mathrm{bp}$ (T2) from $F 1$ to $R 3,698 \mathrm{bp}$ (T3) from $\mathrm{F} 2$ to $\mathrm{R} 1,426 \mathrm{bp}$ (T4) from $\mathrm{F} 2$ to $\mathrm{R} 3$, and $175 \mathrm{bp}$ (T5) from F1 to R2 (Fig. 1).

PCR amplification. For reverse transcription, viral RNA from purified SJNNV, or total nucleic acids from striped jack larvae, was pre-heated at $90^{\circ} \mathrm{C}$ for $5 \mathrm{~min}$ and incubated at $42^{\circ} \mathrm{C}$ for $30 \mathrm{~min}$ in $20 \mu \mathrm{l}$ of PCR buffer (10 mM Tris- $\mathrm{HCl}, \mathrm{pH} 8.3,50 \mathrm{mM} \mathrm{KCl}$ ) containing $2.5 \mathrm{U}$ of M-MLV reverse transcriptase (USB), $1.0 \mathrm{U}$ of ribonuclease inhibitor (Toyobo), $0.5 \mu \mathrm{M}$ of reverse primer, $1 \mathrm{mM}$ each of 4 deoxynucleotide triphosphates (dNTP: Pharmacia), and $5 \mathrm{mM}$ of $\mathrm{MgCl}_{2}$. Following cDNA synthesis, the mixture was incubated at $99^{\circ} \mathrm{C}$ for 10 min to inactivate the reverse transcriptase and then diluted 5-fold with PCR buffer containing $0.1 \mu \mathrm{M}$ of forward primer, $2.5 \mathrm{U}$ of Tth Version 2.0 DNA polymerase (Toyobo) and $2 \mathrm{mM}$ of $\mathrm{MgCl}_{2}$. The mixture was incubated in an automatic thermal cycler (Astec PC-700) programmed for 1 cycle at $72^{\circ} \mathrm{C}$ for $10 \mathrm{~min}$ and $95^{\circ} \mathrm{C}$ for $2 \mathrm{~min}$, then 25 cycles at $95^{\circ} \mathrm{C}$ for $40 \mathrm{~s}$, $55^{\circ} \mathrm{C}$ for $40 \mathrm{~s}$, and $72^{\circ} \mathrm{C}$ for $40 \mathrm{~s}$, and finally held at $72^{\circ} \mathrm{C}$ for $5 \mathrm{~min}$

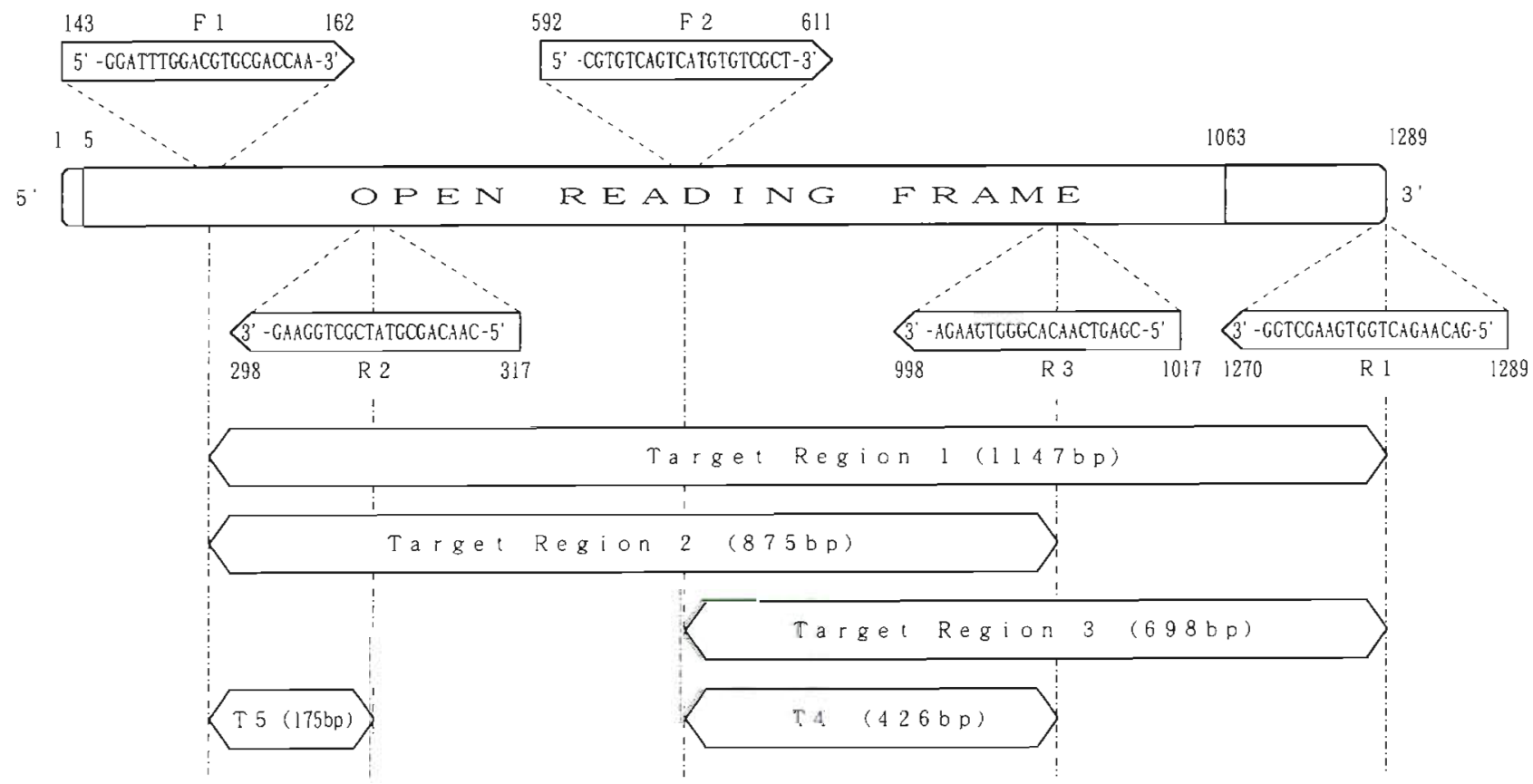

Fig. 1. Schematic illustration of the physical map of the SJNNV RNA2, 2 forward primers (F1 and F2), 3 reverse primers (R1, R2, and R3), and 5 target regions (T1, T2, T3, T4 and T5) for PCR amplification of SJNNV gene 
Table 1. Sequence, location, and characterization of the oligonucleotide primers used in PCR amplification of SJNNV gene

\begin{tabular}{|c|c|c|c|c|}
\hline Primer & Sequence & Location on cloned cDNA & $\% \mathrm{GC}$ & $\operatorname{Tm}\left({ }^{\circ} \mathrm{C}\right)$ \\
\hline F1 & 5'-GGATTTGGACGTGCGACCAA-3' & $143-162$ & 55 & 65.4 \\
\hline F2 & 5'-CGTGTCAGTCATGTGTCGCT-3' & $592-611$ & 55 & 64.5 \\
\hline R1 & 5'-GACAAGACTGGTGAAGCTGG-3' & $1270-1289$ & 55 & 64.8 \\
\hline $\mathrm{R} 2$ & 5'-CAACAGCGTATCGCTGGAAG-3' & $298-317$ & 55 & 63.6 \\
\hline R3 & $5^{\prime}-\mathrm{CGAGTCAACACGGGTGAAGA-3^{ \prime }}$ & $998-1017$ & 55 & 64.4 \\
\hline
\end{tabular}

Analysis of PCR amplified products. Aliquots $(10 \mu \mathrm{l})$ of amplified products were electrophoresed in a $3.0 \%$ NuSieve 3:1 agarose (Takara) - TAE buffer $(40 \mathrm{mM}$ Tris-acetate, pH 7.2, 1 mM EDTA) gel, then the nucleic acids were stained with ethidium bromide. For Southern hybridization, the gel was treated with $0.5 \mathrm{~N}$ $\mathrm{NaOH}-0.6 \mathrm{M} \mathrm{NaCl}$ and then with $0.5 \mathrm{M}$ Tris- $\mathrm{HCl}$ $(\mathrm{pH} 7.4)-0.9 \mathrm{M} \mathrm{NaCl}$. The nucleic acids in the gel were transferred to a nylon membrane (Hybond; Amersham International) by diffusion blotting in $6 \times \mathrm{SSC}(1 \times \mathrm{SSC}$ is $15 \mathrm{mM}$ sodium citrate, $150 \mathrm{mM} \mathrm{NaCl}$ ). After washing with $2 \times \mathrm{SSC}$, the membrane was baked at $80^{\circ} \mathrm{C}$ for $2 \mathrm{~h}$ to bind the DNA, then incubated at $60^{\circ} \mathrm{C}$ for $6 \mathrm{~h}$ in prehybridization solution containing $5 \times \mathrm{SSC}, 50 \%$ (v/v) formamide, $0.5 \%(\mathrm{w} / \mathrm{v}) \mathrm{N}$-lauroylsarcosine, $0.1 \%$ $(\mathrm{w} / \mathrm{v})$ SDS, and $5 \%(\mathrm{w} / \mathrm{v})$ blocking reagent (Boehringer Mannheim Yamanouchi). The cDNA against SJNNV RNA2 was labeled with digoxigenin (DIG) using a DIG labeling kit (Boehringer Mannheim Yamanouchi) and hybridization was performed at $42^{\circ} \mathrm{C}$ for $12 \mathrm{~h}$ in prehybridization solution containing $50 \mathrm{ng}$ of the DIG- labeled probe. Detection of the DIG probe, hybridized with targed DNA on the membrane, was performed as described by the manufacturer.

\section{RESULTS AND DISCUSSION}

Five targeted regions, T1 to T5, of SJNNV RNA2 were amplified by PCR using primer sets F1-R1, F1-R3, F2-R1, F2-R3 and F1-R2, respectively (Fig. 1). The amplified products were analyzed by agarose gel electrophoresis (Fig. 2A). The products of targets T5 and T4 were approximately $180 \mathrm{bp}$ and $430 \mathrm{bp}$, respectively. A major band of about $700 \mathrm{bp}$ and 2 minor bands of about $630 \mathrm{bp}$ and $120 \mathrm{bp}$ were detected by amplification of the T3 target region using primer set F2-R1. A major band of about $880 \mathrm{bp}$ and a minor one of about 710 bp were observed by amplification of the T2 target region. The amplification of the T1 target region yielded 2 major DNA segments (about 1150 and $1080 \mathrm{bp}$ ) and 3 minor segments (about 880, 570 and

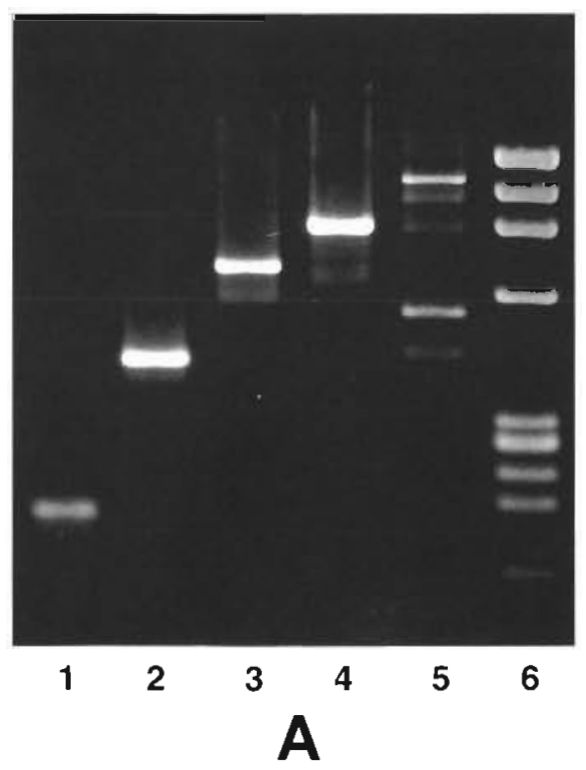

1358

872

603

310

234

194

118
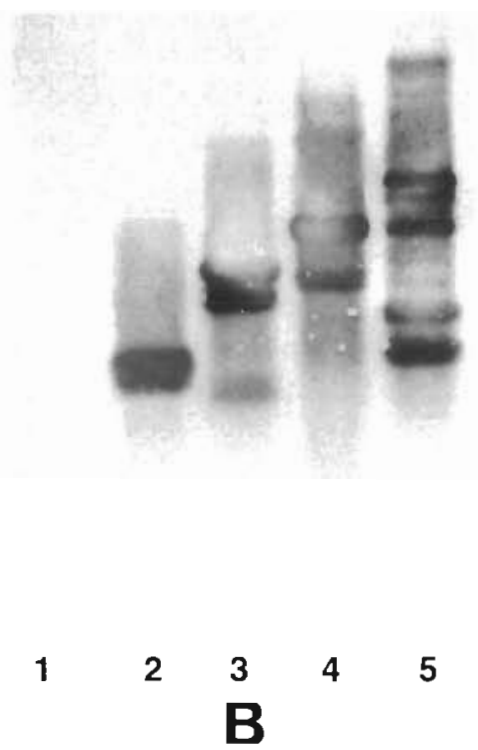

Fig. 2. Agarose gel electrophoresis of the products by PCR amplification of 5 target regions of SJNNV gene. (A) Agarose gel stained with ethidium bromide, (B) Southern blot hybridization with DIG-labeled cDNA to SJNNV RNA2. Lanes: (1) T5, (2) T4, (3) $\mathrm{T} 3$, (4) T2, (5) T1, (6) DNA ladder 


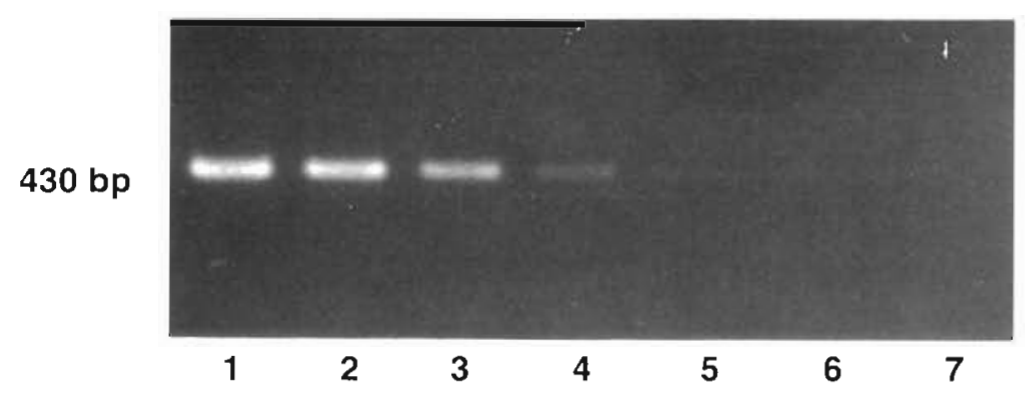

Fig. 3. Detection limit of SINNV gene by PCR amplification with 25-cycle incubation. Amplified products in agarose gel were stained with ethidium bromide. Lanes: (1) $100 \mathrm{pg}$ of SJNNV RNA, (2) $10 \mathrm{pg}$, (3) $1 \mathrm{pg}$, (4) $100 \mathrm{fg}$, (5) $10 \mathrm{fg},(6) 1 \mathrm{fg},(7) 0 \mathrm{~g}$

$430 \mathrm{bpj}$. All of these amplified products hybriaized with the DIG-labeled cDNA probe against SJNNV RNA2 (Fig. 2B). However, the F1-R1, F1-R3, and F2-R1 primer sets and their corresponding target regions, T1, T2 and T3, were not considered useful for PCR amplification since products other than those of the predicted molecular weights were obtained. These nonspecific background products might be produced by partially renatured secondary structure(s) of SJNNV RNA2 at the temperature for the reverse transcriptase reaction. The amplification of these nonspecific products could be eliminated by changing the combination of the primers used, suggesting that the secondary structure may have existed in the larger target regions of the original primer sets. Although nonspecific products were not observed in the PCR amplification of T5 and T4, the product from T5 was less stained than that from T4. From these results, T4 was considered to be the most suitable target region tested for PCR amplification of the SJNNV coat protein gene.

The detection limit of SJNNV RNA by PCR amplification was examined using 10 -fold serially diluted samples of RNA ranging from $100 \mathrm{pg}$ to $1 \mathrm{fg}$. The F2-R3 primer set was used with 25 cycles of amplification. A single species of DNA product (about $430 \mathrm{bp}$ ) was detected from the samples containing more than $100 \mathrm{fg}$ of SJNNV RNA, but not from samples with $10 \mathrm{fg}$ or less (Fig. 3). By increasing the number of PCR incubation cycles to 35, it was possible to detect a smaller quantity of SJNNV RNA, down to a level of approximately $0.1 \mathrm{fg}$.

Total nucleic acids from diseased and normal larvae of striped jack were subjected to amplification of the T4 region by PCR. The amplification using nucleic acids from diseased larvae yielded a large amount of 430 bp DNA product corresponding to that obtained from SJNNV RNA. No product was detected from nucleic acid samples from nor- mal larvae (Fig. 4A). The amplified product from infected larvae hybridized with the cDNA of SJNNV RNA2 (Fig. 4B), confirming that the specified viral target was amplified in the reaction. In addition to being useful for detection of SJNNV from diseased larvae, the target sequence of the SJNNV gene was amplified by PCR from nucleic acids of infected larval striped jack from which SJNNV antigens were not detected by ELISA (data not shown). This demonstrates the PCR amplification of SJNNV nucleic acid to be a specific and sensitive method for the diagnosis of VNN

Diseases of larval or juvenile marine fish with viral etiology similar to VNN in striped jack were also reported in Japanese parrotfish Oplegnathus fasciatus (Yoshikoshi \& Inoue 1990), barramundi Lates calcarifer (Glazebrook et al. 1990, Renault et al. 1991, Munday et al. 1992), turbot Scophthalmus maximus (Bloch et al. 1991), sea-bass Dicentrarchus labrax (Breuil et al. 1991) and redspotted grouper Epinephelus akaara (Mori et al. 1991) in Japan and other countries. However, the causative viruses have been neither isolated nor purified from these diseased fish and no comparative studies of these agents have been done. Products identical to that obtained from SJNNV were amplified from diseased Japanese parrotfish and redspotted grouper by PCR using the primer set designed to amplify the T4 region of SJNNV RNA2, and they were hybridyzed with the CDNA against SJNNV RNA2 (data not shown). This amplification method will be useful for comparative studies of VNN disease agents.

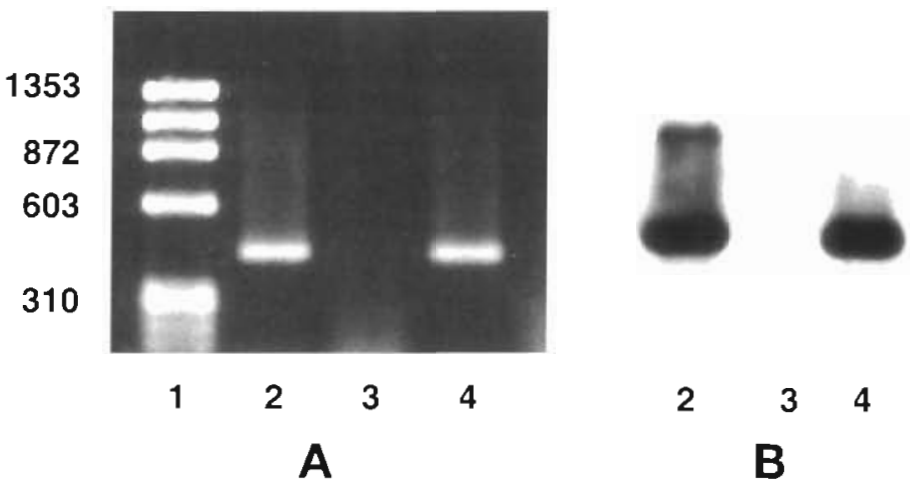

Fig. 4. Detection of SJNNV gene from larval striped jack $P_{\text {seudocaranx }}$ dentex by PCR amplification. (A) Agarose gel stained with ethidium bromide, (B) Southern blot hybridization with DIG-labeled CDNA to SJNNV RNA2. Lanes: (1) DNA ladder, (2) amplified product from SJNNV gene. (3) amplified product from total nucleic acids extracted from normal striped jack, (4) amplified product from total nuclesc acids extracted from diseased striped jack 
Acknowledgements. The authors express their gratitude to Dr J. R. Winton of the National Fisheries Research Center, Seattle, for his valuable suggestions for this study. This research was supported in part by a Grant-in-Aid for Scientific Research from the Ministry of Education, Science and Culture of Japan.

\section{LITERATURE CITED}

Arakawa, C. K., Deering, R. E., Higman, K. H., Oshima, K. H., O'Hara, P. J., Winton, J. R. (1990). Polymerase chain reaction (PCR) amplification of a nucleoprotein gene sequence of infectious hematopoietic necrosis virus. Dis. aquat. Org. 8: $165-170$

Arimoto, M., Mori, K., Nakai, T., Muroga, K., Furusawa, I. (1993). Pathogenicity of the causative agent of viral nervous necrosis disease in striped jack, Pseudocaranx dentex (Bloch \& Schneider). J. Fish Dis. 16: 461-469

Arimoto, M., Mushiake, K., Mizuta, Y., Nakai, T., Muroga, K., Furusawa, 1. (1992). Detection of striped jack nervous necrosis virus (SJNNV) by enzyme-linked immunosorbent assay (ELISA). Gyobyo Kenkyu (Fish Pathol.) 27: 191-195

Bloch, B., Gravningen, K., Larsen, J. L. (1991). Encephalomyelitis among turbot associated with a picornavirus-like agent. Dis. aquat. Org. 10:65-70

Breuil, G., Bonami, J. R., Pepin, J. F., Pichot, Y. (1991). Viral infection (picorna-like virus) associated with mass mortalities in hatchery-reared sea-bass (Dicentrarchus labrax) larvae and juveniles. Aquaculture 97: 109-116

Glazebrook, J. S., Heasman, M. P., de Beer, S. W. (1990).

Responsible Subject Editor: F. M. Hetrick, College Park, Maryland, USA
Picorna-like viral particles associated with mass mortalities in larval barramundi, Lates calcarifer (Bloch). J. Fish Dis. 13: $245-249$

Innis, M. A., Gelfand, D. H., Sninsky, J. J., White, T. J. (1990). PCR protocols: a guide to methods and applications. Academic Press, New York

Mori, K., Nakai, T., Muroga, K., Arimoto, M., Mushiake, K., Furusawa, I. (1992). Properties of a new virus belonging to Nodaviridae found in larval striped jack (P $P_{\text {seudocaranx }}$ dentex) with nervous necrosis. Virology 187: 368-371

Mori, K., Nakai, T., Nagahara, M., Muroga, K., Mekuchi, T., Kanno, T (1991). A viral disease in hatchery-reared larvae and juveniles of redspotted grouper. Gyobyo Kenkyu (Fish Pathol.) 26: 209-210

Munday, B. L., Langdon, J. S., Hyatt, A., Humphrey, J. D. (1992). Mass mortality associated with a viral-induced vacuolating encephalopathy and retinopathy of larval and juvenile barramundi, Lates calcarifer Bloch. Aquaculture 103: 197-211

Renault, T., Haffner, Ph., Baudin Laurencin, F., Breuil, G., Bonami, J. R. (1991). Mass mortalities in hatchery-reared sea bass (Lates calcarifer) larvae associated with the presence in the brain and retina of virus-like particles. Bull. Eur. Ass. Fish Pathol. 11: 68-73

Yoshikoshi, K., Inoue, K. (1990). Viral nervous necrosis in hatchery-reared larvae and juveniles of Japanese parrotfish, Oplegnathus fasciatus (Temminck \& Schlegel). J. Fish Dis. 13: $69-77$

Xu, L. Z., Larzul, D. (1991). The polymerase chain reaction: basic methodology and applications. Comp. Immun. Microbiol. infect. Dis. 14: 209-221

Manuscript first received: June 30,1993

Revised version accepted: October ?, 1993 